\title{
Educational Value and Character in Pappaseng Bugis (Buginese Message)
}

\author{
Syamsudduha \\ Universitas Negeri Makassar, Indonesia \\ Kamaruddin \\ Universitas Negeri Makassar, Indonesia \\ Hawang Hanafi \\ Universitas Negeri Makassar, Indonesia \\ Muhammad Rapi Tang \\ Universitas Negeri Makassar, Indonesia
}

\begin{abstract}
The Buginese community in South Sulawesi is a society that lives in powerful custom systems. The custom was deeply held by its ancestor since ancient times until now. Pappaseng or message as one of the Buginese communities' cultural products is known by the philosophy of the Buginese community living. It is loaded with educational values, which can be adopted in designing an education-based character. This article presents the fundamental values as the Foundation in action. The values are already widespread in the systems of Buginese community living. It also shows that there are many local wisdom values, which are buried deep in the Buginese community culture packaged in the panngadereng or custom. The custom can be the spearhead in the influx of other cultures that dismissed the damage the morality of the Indonesian nation generally and the Buginese society, particularly.
\end{abstract}

Index Terms - Buginese message, educational, values, character, local

\section{INTRODUCTION}

This paper is based on some of the writings of either in the form of research results, the papers presented at national or international seminars. There are some articles about issues that developing currently regarding to educational character, and text books about pappaseng. In addition, this paper is also based on the contents of the papers that have been presented by the author at the International Congress II of Regional languages of South Sulawesi, MakassarIndonesia on 1-4 March 2011 at the Hotel Sahid Makassar entitled "Value and character education in Pappaseng: Representation of community norms and Philosophical Life of Buginese." There are some researches related to the meanings contained in the pappaseng. The researches were conducted by Mattulada (1995) which had been published in book form in (1995), D.M. (1997) Said, the $\operatorname{MoE}$ (2000; 2010), Rosmawati (2003). Specifically, this paper aims to introduce the wisdom of Buginese scholars in the past through the largest document after the writing of the literary works of Galigo. Pappaseng found in a classic script called Lontaraq of Bugis written since several centuries ago. The effort to preserve the contents of the pappaseng has been performed by rewriting the pappaseng script, either in the form of transcriptions of Lontaraq letters into the Latin alphabet, as well as in various other research results as has been done by Matthes (1872; 1937), Haddade (1986), Mattalitti, et al. (1986), Ambo Enre, et al. (1985), Punagi (1989) and some other text book.

This paper aims at revealing the sublime values contained in pappaseng which are still considered relevant to people's lives up to this point so that it can be one alternative educational values and character. Educational values and character basically have been running for a long time along with education in General. The educations are packaged in a variety of forms, such as: education of moral, education of ethics, and education of character. Nevertheless, the urgency of the education of values and character is not detached from the community sociocultural conditions.

Condition of Indonesian community currently shows that there has been a pretty horrible in tossing them into civilization of nation. Fundamental values such as the recognition of rights of people life are no longer the foundation for the action made by various groups of people in different areas. Compassion has been replaced by hatred being waged by various ethnic groups, religions, political party members, even by a community that historically has a soul and high mutual solidarity, i.e. community areas that are already being eroded. Awareness of self-esteem and empathy were destroyed by the explosion of uncontrolled emotion. The phenomenon such as this can be seen everywhere.

A very regrettable condition is compounded by the decline of morality, customs, norms violated, and the value of honesty seems to have been buried by lies and deception. 
It is undeniable that social and cultural situation for society of South Sulawesi generally and Buginese society particularly was increasingly alarming, as expressed by some educational observers. Koesoema A (2010) expressed that there are a variety of educational events in the increasingly degrading human dignity and degree. The destruction of moral values, a new outbreak of injustice, depletion of solidarity, and others have taken place in our educational institutions. This invites a question that the extent to which the institution has been able to answer and perceptive about the various problems that occur in the community. Thus, it is necessary for a more approach and effective strategy.

One of the best solutions according to the view of the author is a community of Buginese should keep up to its cultural values. One of the cultural products loaded with value is pappaseng. Therefore, this paper specifically aims to reveal: (1) the value of education contained in the pappaseng (2) the importance of educational values in pappaseng, (3) the process of pappaseng to be alternative educational values and character.

\section{METHODS}

\section{A. Data Sources}

The Data in this paper were written in the form of the citation text data of the pappaseng deriving from the results from the Lontaraq letter transcription into the Latin alphabet that had been conducted by Ambo Enre, et al (1985), Mattalitti, et al (1986), Haddade (1986), Mahmud (1986), Punagi (1983), and other supporting reference.

\section{B. Data Collection Techniques}

Data were collected by studying the document by setting the text purposively toward some of the transcriptions in the pappaseng that had been conducted by researchers and other references by reading the text, doing the encoding on a corpus of data collected.

\section{Data Analysis Techniques}

Data were analyzed by three stages, namely: identifying data of pappaseng based on values containing the educational characters, classifying data based on the coding conducted before, interpreting and making conclusion.

\section{RESULT AND DISCUSSION}

\section{A. Educational Values and Character in Pappaseng}

The words of value and character are often mentioned and known by many people. Nevertheless, there are still too many people who ignore it. Characters need to be built, created, nurtured and developed. Character is influenced by environmental conditions such as family, community, as well as life of country and State. In order to achieve it, the values need to be established. The value for this is often interpreted as everything that can satisfy the needs and desires of human. The value can also be a quality self of something that may produce an award response so that it can be felt by every human being without through sensory experience first.

Lexically, the value is interpreted as (1) price (price estimate), (2) price of money, (3) figures for cleverness, (4) level, (5) important things that are useful to humanity (Alwi, et All., 2004, p. 690). In this paper, the value is defined as all things or things that are important and useful for human life.

From some definition above, it can be concluded that the values cannot be separated from human life. Value has always been a standard which directs every action or human performance.

There are many different types of value paraphrased from various posts, namely: (1) moral/ethical values; (2) religious values; (3) cultural values; (4) the value of education; and (5) philosophical value.

Furthermore, in this paper, the author provides a discussion on cultural values contained in pappaseng which is considered that the values can give a large donation in educational values and character.

Pappaseng comes from the word "paseng". It means a message (Said, 1977, p. 151). It includes advice, tips, and a will to be known and implemented.

Pappaseng holds values, suggestions and guidance from predecessors or ancestor of the Buginese in the past for his granddaughter to live life well (Mattalitti, 1986, p. 6). Thus, the pappaseng needs to be preserved as a manifestation of the Buginese people compliance to the ancestors.

Sikki, et all.(1998) explained that pappaseng in Buginese language has the same meaning with testament in Indonesian language. It has the synonym of pangaja' advice, but both these words have different nuance of meaning.

Another explanation that pappaseng is the testament of the parents to the child, his grandson, or people that should always be remembered as a mandate that needs to be followed and implemented based on believing in yourself with a sense of responsibility (Punagi, 1983).

From some of the pappaseng concept summarized from various writings, it can be concluded that pappaseng contains tips, which should always be remembered as a mandate from its ancestors that need to be performed with a full sense of responsibility. Thus, it is no wonder that pappaseng is a philosophy of life as part of a community of Bugis in South Sulawesi. From the writings, it is also explained that pappaseng contains a big idea, a noble mind fruit, precious soul, and a sublime attention on the nature of the positive and negative. 
Pappaseng is like any wisdom or policies. It always displaces value throughout history that took place. However, the value will remain unchanged through the ages, consistent and in accordance with the philosophy of the State as a national shared asset value together.

Some examples of pappaseng and major substances contained in it and served as a living community of Bugisnese order since long ago, are expressed as follows:

\section{The Values of Alempureng (Honesty)}

Honesty is one of the fundamental values of human life. This value becomes the main basis in the social fellow human beings interact. It is one of the factors coloring the behavior and actions of human beings. Pappaseng to riolo 'ancestral advice' is expressed as follows:

Makkedai To rioloé: "Nakko engka muéloreng napogauq taué, rapanngi lopi. Maéloqpo tonangiwi mupatonangianngi taué. Iyanaro riaseng malempuq makkuwaé."

\section{Meaning:}

'Old people or ancestors said: "If there is something you want done by someone else, think of it as a boat. If you own ready to appropriate it, then you have other people to utilize it. So that it is called honesty. (Ambo Enre, at. All., 1985, p.10).

The Pappaseng explains how honesty should be conducted by everyone. In the pappaseng, there is an implied meaning that anyone who wants others to comply in carrying out what it wants, first he/she is positioning himself as the one who asked for it compliance.

There are also pappaseng which present advice to always be honest, who quoted from a conversation between Laliddong and Kajao Arumpone as follows:

Ajaq muala waramparang narekko tania waramparammu,

Ajaq muala aju ripasanré narékko tania iko pasanréi,

Ajaq muala aju riwetta wali narekko tania iko mpettai.

\section{Meaning:}

'Do not take things that are not yours, Don't take the kept wood if you don't save it, Do not take a cut out of the wood if it was not you who cut the wood.'(Haddade, 1986, p.15).

The Pappaseng reveals the habits of the person resting or cut off both ends of the wood taken in the forest as a sign that the wood was already owned by someone. In the pappaseng, there is a message for not to take something that does not belong to us.

There are three basic concepts to achieve honesty, which is contained in pappaseng. They are siri' (shame); precautions or careful approach, and fear that accompanied the thoroughness. They are reflected in the following pappaseng:

Naiya appongenna lempuqé tellunrupai:

Seuwana, iyapa nqapoadai kadopi molai;

Maduwanna, iyapa napogauk-i kadopi lewuriwi ri munripi tau-é

Matellunna, tennaenrekie waramparang ri palolok, tennassakkarenngi ada-ada maddiolona

Meaning:

'There are three things that became the base of honesty; First, say when willing to perform Second, carry out when it is able to assume the risk Third, do not accept bribe goods, and does not contradict the words ever spoken.' (Ambo Enre, at. all. 1985, p. 10).

The message conveyed in the Pappaseng implies that an honest does not easily decide something, but he will observe first before conducting. An honestly person is not accepting goods bribery, and does not violate the word ever uttered.

Furthermore, the idea of honesty is also expressed in the Pappaenna To Maccaé ri Luwu as follows:

Aruwai sabbinna lempu-é, iyanaritu:

Napariwawoi ri wawo-é

Napariyawai ri yawa-é

Napariatauwi atawu-é

Naparilaenngi ri lalenng-é

Napari abeoi abeo-é

Naparisaliwenngi ri saliwenng-é

Naparimunriwi ri munri-é

Napariyoloi ri yolo-é

Meaning:

There are eight characteristics of honesty:

Placing on top, something decent on top

Placing on bottom, something decent on bottom

Placing on right, something decent on right

Placing on left, something decent on left

Placing inside, something decent inside

Placing outside, something decent outside 
Placing behind, something decent behind

Placing in front, something decent in front

Ambo Enre, (1985, p.26)

The Pappaseng conveys the message that honesty is the judge something objectively. Honesty also means putting something according to his position, and resolving problems fairly and wisely. The Pappaseng is required in particularly in enforcing justice.

\section{Réso (Value of hard work)}

In relation to the work ethic, historically known as the Bugis sailors accomplished. Because familiar with the water and the sea, the dynamic properties of waves that are always moving and do not want to calm the soul and that is what affects the mind (Said, 1997). It is described as a dynamic nature, full of zeal without relentless and unflinching pappaseng which can be seen in the following:

Pura babbara sompekku

Pura gucciri gulingku

Ulebbirenngi tellenngé natowalié

\section{Meaning:}

'My screen has grown, My steering wheel is mounted, Rather than re-sunk Chosen' Amir, et.all., (1982, p. 56)

The great nature, never retreats, and never gives up if people want to achieve something that is described in the pappaseng. However, high trait was controlled also in the pappaseng below:

'Narékko moloiko roppo-roppo,

Rewekko mappikkirik

(Amir, et.all., 1982, p. 56)

\section{Meaning:}

'If you go and see the bush, Let's thinking.

The pappaseng conveys that any of the desire to achieve something, if you encounter any obstacles or barriers back thinking about it. There is also pappaseng found in élompugi form that has been very popular among the Bugis, as follows:

\section{Résopa temmanginngi}

Namalomo nalétéi

Pammasé déwata

\section{Meaning:}

'Only the diligent work, Often become catwalks, Ilahi grace"

The pappaseng conveys the message that perseverance and hard work continue to be the beginning of success. Therefore, if you want to succeed must be coupled with an attitude of despair abstinence, patience, and work selflessly and sincerity.

\section{Assitulung-Tulungeng, Assiwolompolongeng (Value of Mutual Cooperation)}

There is an interesting statement from the Dutch that the Bugis-Makassar should not be because of undisciplined soldiers. All of them want to be a commander. And these properties are visible when sailing not to be outdone and should always be Ponggawa (Amir, et. all., 1982).

However, behind the strong character, there is also a positive attitude that the people of South Sulawesi, although the traditional but the most powerful and have solidarity and mutual cooperation properties. It is revealed in the following pappaseng:

Rebba sipatokkong

maliq siparappé

malilu sipakaingeq

\section{Meaning:}

'Sit back, mutually enforcing, Washed, each strand, Commemorating for mistake each other.' (Mattalitti, 1986, p.13).

The Pappaseng conveys the significance of mutual support. It reminds one another if anyone made a mistake, and the pappaseng refers that since ancient Bugisnese people do not like the philosophy of holding each other down, but the opposite is the belief that needs to be invested in helping each other in distress.

\section{Agettengeng (Value of Firmness)}

In the language of the Bugis, firmness can be called getteng, which can also be interpreted assertive, tough, and steadfast belief and consistent. In relation to this constancy, pappaseng Arung Bila, cited below:

"Tellu riala toddok:

Getteng,

Lempuq,

Ada tongeng

Meaning:

'There are three things that can be used as a benchmark, is:

Tenacity,

Honesty, 
True Speech'

(Mahmud, 1986, p. 23)

4. Value of awaraningeng 'Courage'

The values associated with courage depicted in pappaseng Arung Bila as follows:

"Akguruiiwi gaukna to warani-é, enrenng-é ampéna, apak iya gaukna to warani-é, seppuloi wawangenna seuwana jana.

Jajini asera decenna. Iyanaro nariyaseng maja seddi-é nasabak matei. Naé topellorenng-é maté muto.

Naiya decenna to warani é:

Seuwani, tettakkini napolei ada maja

Maduawanna, tennajampangiwi kareba-é

Matellunna, temmatau-i ripalao ri yolo

Maeppana, temmatau-i ri paonro ri munri

Malimanna, temmatau-i mita bali

Maennenna, ri asirik-i

Mapitunna, riala-i passappo ri wanuwa-é

Maruwana, Matinuluk-i pajaji passurong

Maserana, rialai pakdekbak tomawatang"

Masirik toi, riasirik toi ri padanna tau

(Mattaliti, 1986, p. 19)

\section{Meaning:}

'Study the nature of the brave

Intrepid nature because there are ten kinds

Only one facing death ugliness as easy

Nevertheless, timid will not escape death, cause of death inevitable for animate beings.

Goodness brave, there are nine:

Not surprised to hear bad news or good news,

News that was heard not ignored but accompanied with energy

Not afraid to put forward, not afraid neglected in favor

Not afraid to see the enemy

Shield Made by the State

Diligent obligations

Being a defender of the people who apply arbitrary

Respect and also respected by his fellow human beings

In the above pappaseng, the message conveyed that everyone learns to be brave. He also said that the properties of the brave have nine kindnesses, and only the ugliness, because it is easy to face death. However, the timid will never be able to avoid death or death. Therefore, it is better than not die because the fight against but dead too. That is one of Bugis philosophy sourced from pappaseng. The expected value of such courage as a leader is to run the authorities.

\section{Sipakatau (Value of Mutual respect)}

Sipakatau in pappaseng contains in the following:

... Seuwatopi adeqna makkasuwianngé ri arung mangkauq. Nakko kuiq ri olona arung mangkaué, ajaq nalainngé taita. Arunngemusa tamata-mata, muitai paturung élona enrenngé adanna. Ajaq muassailé uleng nakko naéwao ada arunngé. Ajaqto muamiccu ri olomu. Ajaqto muattulekkeng. Ajaq muakkita uleng. Apaq nakko siduppa matao liseq bolaé musicabéruseng, ripettu tigeroqko, muko sisseng rigangkamuna. Padatoi nakko siéwao ada liseq bolaé, itai baténa mappau, batténa moloiwi paturung élona arunngé naiato muppapadai...(Ambo Enre, at. all. 1985, p. 19).

Meaning:

'One more customary to serve the reigning king, if we are in the presence of the king does not see the others. The king alone is deemed that you see what his wishes. Do not turn left and right if the king talks to you. Do not spit in front of him. Do not also recline. Do not look here and there because if you meet with chapel of view, then you smiled at each other, you will be killed even if you did know each other. As well as, if you are conversing with ancillary, will look at how to carry on serving the king, and that's what you aspire to be.'

Pappaseng explains the rules of thumb in doing service to the king, especially if a man of dealing directly with the king. Speakers wanted to teach the public discourse about how to interact with people of higher social status; the person must ripakalebbiq 'glorified,' people must be upheld and respected as a form of nature sipakatau 'mutual respect.' Environment kingdom laden with rules and manners so that the necessary acquaintance and habituation. The rules of thumb that is felt by the makers as critical discourse disseminated to the public for everyone to know and understand. With that understanding arung mangkauq as royal leader easily conquer the hearts of his people. From the pappasemng, learned the nature of the information about the importance of mutual respect and respecting each other, either as a subordinate-supervisor and vice versa, parent-child, or vice versa, and among humans.

Sixth is the value that has been described is a fundamental human value that can be a solid foundation in the formation of national character. These values have been taught by Bugis scholar in the past and have been entrenched in 
the life of Bugis society since time immemorial. However, this time has been eroded even if virtually been ravaged buffeted by the changing times and the rapid globalization incredible powerful.

\section{B. Why Educational Value Is Important in Pappaseng?}

Concerns about the state of education and the value of the character has been revealed by education experts in Indonesia, including; Soedarsono (2008), Rahman (2013), and a wide range of expert opinion that the current level of education has lost its way (Sutaryo, 2012).

Basically, the interest that educational efforts are not able to maintain the essence of man as nature, creature's sacred creation of God, the Glorified, only now it is not the case, but has surfaced since many centuries ago. As noted by the German philosopher Immanuel Kant very prominent (1724-1808) that human beings will not be able to recognize him, but the man will be able to identify him based on what looks from the outside of him either empirically or in spirit (Rahman, 2013).

Concerns also have been raised by the leaders of the world long ago, as has been stated by Mahatma Gandhi who warned that one mortal sin, namely "education without character" 'education without character.' Similarly, Martin Luther King who once said: "Intelligence plus character .... that is the goal of true education" 'Intelligence plus character .... it is the ultimate goal of real education.' Similarly, Theodore Roosevelt once said: "To educate a person in mind and not in Morals is to educate a menace to society" Educating someone in the intelligence aspect and not the moral aspect is the danger to the public. (Ani Putra, 2013, p. 1).

The attentions of the various parties indicate that educational conditions serious, and should be taken seriously, and one of the best alternatives according to the author, is "Revert to Its Cultural Society." Within the meaning of the concept of culture includes ways of thinking, perspectives, and beliefs that can create the foundation of a value establishment attitude, behavior, and community action.

In Bugis of South Sulawesi, pappaseng has long been a philosophy of life, but is now also experiencing a shift in value or may otherwise public life has grown so rapidly in the current global era that affects thought patterns, beliefs, attitudes, behavior and actions of society. What happens in the middle of Bugis society today is a symptom of a shift in the value of life. Faisal (2010) expressed that the complexity values faced by society today is completely degraded, hedonic behavior, instant, materialistic, and individualistic.

Given this reality, efforts to change the mind-set and lifestyle of people are very difficult. Global flows the stronger and continue to urge the government and is now busy looking for alternative solutions and effective educational strategies to realize a character-based education. What to do in such circumstances, the authors argue that the best solution is to restore the livelihood of people in the values of local wisdom that has been rooted and entrenched in society. The Bugis in South Sulawesi, in particular, is supposed to return the mirror to the back of Bugis society has a history that panngadereng 'mores' are packed in the pappaseng 'counsel; advice' ingenious-clever people in the past can be an alternative to character education that is very telling, "Why doubt?" very prominent German philosopher Immanuel Kant (1724-1808) said that humans would be able to recognize him by what looks from the outside of him either empirically or in spirit (Rahman, 2013). This view can also be the rationale that if the man is a failure in recognizing his flesh, then he should be stimulated to recognize himself inwardly, and one effective way to do is bringing them closer to their cultural roots, which had been fused with the inner since they were born.

Why a view to re-strengthen the values for the Bugis pappaseng this important? The author had a strong belief that without concern for the values of local wisdom and allow the system panngadereng 'custom' ravaged buffeted by currents of modernization with global lifestyle is very strong, the character of this nation will be crushed to pieces. Moralities become something that is not important anymore, violence, berating each other and destroy each other it does not matter anymore. In short, law violations occur everywhere no matter. All of it is a phenomenon of life in the era of modernization and globalization. This study is based on the view of Jean Jacques Rousseau (1712-1778) French philosopher Social Contract with the view that calls for togetherness value is used as a social contract regardless of whether the social status of the nobility or of the bourgeois class. If the law is not functioning optimally, then the social contract that is functioning to provide social sanction for the offender. Based on that consideration, pappaseng values are expected to continue to exist and be a social contract that can control any attitude, behavior, and community actions that deviate from the norms and values.

\section{Pappaseng as an Alternative to Educational Values and Character}

The first major movement in the education value with the value realization term introduced by Sidney Simon in 1980 (Zuchdi, 2009). The next movement is called value realization approach. This approach includes all strategies to help someone determine, implement, realize, act and reach the values they believe in life including the approach realization value. This was further developed as a life skills education that teaches the knowledge and skills that can help the younger generation steer themselves in the life of a versatile compound. Have been many curriculum and methods of education which has been developed to help young people develop skills to realize values, be those effective in all situations, and define the meaning of life. The main thing is to know yourself-education, awareness of self-worth, skills to formulate goals, thinking, decision making skills, social skills, communication skills, academic knowledge and transcendental knowledge. How values education for South Sulawesi citizen? Have there are the most effective approaches to values education? The solution is in the hands of people who are competent to instruct. 
The best alternative in improving the quality of educational value needs to be supported. How is the value of education, which is required to enhance the quality of the morals of the subject of the students? How is the use of values education in school and outside of school?

Some forms of bidding strategy of educational values has been put forward by the experts on education, among others, that values education and character can be accomplished by building efficient partnerships between organizations, family, and civic institutions. These statements are often unreadable in text books, but only as a theory.

\section{How are the characters that will be formed?}

What is called character can be understood differently by the thinkers in accordance with their approach and emphasis respectively. Therefore, it is not easy to determine definitively what a character is. However, in this paper the author will discuss some of the issues that arise regarding the understanding of the character.

In general, the character often associated with temperament that presents a definition that emphasizes the psychosocial components that are associated with educational and environmental context. In the opinion of behavioral elements that emphasize the individual owned somatopsychic since birth, is considered equal to the character's personality. In this case the character traits or qualities considered typical of a person deriving from the derivatives received from the environment, including life in the family environment in childhood and one's inherent from birth (A Koesoema, 2010).

The question, "is being shown by someone in mannerisms, personality, or behavior that can be someone already dead from there his cap so that everyone is experiencing natural determinism over what is shown in all his behavior and temperament?" Suppose determinism rightly is the extent to which a person is able to have the freedom to solve it?

Talk about character of education, inevitably we must critically question the representation of humans such as what is in our minds. What is presented by Koesoema by quoting the words of educational praxis that Freire relies on a concept of man and the world and to answer the questions that appear questions in education, we need to know the structure of the anthropological is inside the man himself and any attempt to understand the character education first of all have to do is answer questions about basic anthropological structure of fundamental nature as human beings.

Basically, in sensory we can distinguish between the kind people and those who are unkind. The question is whether people are kind and unkind that can be said to those who have the virtue and those who do not have primacy. Whether the good habits and virtues that arguably privilege for only certain people who are born with innate since from birth? If that is true, then the character education is certainly not needed anymore. There is no point in character education since basically a kind human will has always worked well and otherwise, every human being who is unkind will always be unkind. This of course caused controversy, because, in fact, researcher see there are just people who are historically known as the unkind, but now the people are kind, and otherwise. What happens in the process of changing it shows that the human has a dynamic power that can change, and if humans have the power of that dynamic, then the character education is certainly a chance that addresses opportunities for the improvement of the human self. Therefore, character education is still needed. How is the best alternative? Listen to the advice of older people.

\section{How are Educational Character Strategies that must be done?}

Character of education aims to teach certain traditional values that are widely accepted as the Foundation of good behavior and responsible. These values are also described as ethical behavior. We often hear people saying that we need to teach values to children, usually meant is traditional values or moral behavior. Due to the biennial donations terms character, traditional values and moral behavior accommodates less obvious meanings that sometimes, even controversial. Some educators also more agree with the term character education (Zuchdi, 2009). On the other hand, the author finds reference entitled Ethics Lecture. This makes the author thinks that there's also the term ethics education. Ethics education is closely associated with the character of a person. The character is an old concept that means a set of traits that have always been admired as a sign of kindness, policies, and moral maturity. Although there are numerous differences, the attributes of good character that becomes the purpose of education. Figures are respect, responsibility, compassion, discipline, loyalty, courage, tolerance, openness, work ethic, and trust, as well as the love of God. The latter is particularly important because the quality of faith largely determine the quality of a person's character or personality.

Based on the description, it can be concluded that character education is difficult to be given strict limits, due to the absence of clear indicators so that as long as this character education emphasis is always focused on making ethical values and morals that are always associated with a person's ability to apply the values that are good and beneficial to life.

Pappaseng values that have been outlined at the beginning of this paper can substantially be alternative values education and character. What strategy must be made in the implementation of those values, the educational system is very dependent on the planned character. Along with the implementation of formal education, character education expressly described three main elements which propose the attitude then skill, and knowledge.

The fundamental substance of the curriculum is the curriculum change from 2013 based on cognitive, affective, and psychomotor changed into attitudes, skills, and knowledge. The orientation of the curriculum is to make changes to the 2013 attitudes and behaviors in learners so that the attitude and behavior in accordance with the values that developed in the community (Sumadi, 2013). This shows the serious efforts of the Government to put forward the formation of attitudes as the Foundation to behave and act. But all this is far from enough, to bring closer the learners with the values 
that prevail in the communities where they live, and then they should learn within the community itself, without being limited to formal education. Therefore, there is no other way of character education should be established early on, must be returned to their Habitat, the habitat in which they are born, grow, thrive in his/her every day, go back into the family as the first and primary school.

Thus, it is no exaggeration to say that character education is a complex, but education can be handled in a simple if that character education system is designed in a simple, meaning that values education and character cannot be done separately, should be done simultaneously, and integrated in the interact anywhere anytime, and with anyone. Character education should be integrated in all the activities. Therefore, anyone can become a teacher. The teacher does not have to be certified, teachers and civil servants also are not to be determined from the highest academic title and high social status, but the teacher is anyone who has feasibility and appropriateness to be exemplary in lived his life, and exemplary figure is actually hard to find in a global era of technologically complex.

Values education cannot be separated with the norm. In its development, the norm is defined as the size, influence lines, or rules, rules for consideration or judgment. A value that belongs together in a community and has been embedded with deep emotion is going to be mutually agreed norms (Zubair, 1995).

Everything that is rated good, beautiful, or useful will be organized for the manifested in deed. As a result of that effort, there are the measurements for any act or norm of action. Per the norm that has been accepted by the society always contains sanctions and rewards. Everything that is done without the line with norms will get punishment, censure, and so on. On the contrary, everything is done in line with the norm will get praise and retribution. Here's what want delivered by intellectuals of Bugis in the past through pappaseng.

3. Strategy for the Delivery of Pappaseng Values as One of Alternatives in Educational Values and Character

A study of the value and the character has long been the subject of attention of psychologists, pedagogy and educators. It called value and character can be understood differently by the appropriate emphasis and thinkers in their respective approaches. Therefore, it is not easy to determine definitively what character it is.

In this paper, the character is understood as a set of values which manifests in a fighting power system informing the thinking, attitudes, and behaviors of human beings. Characters must be realized through moral values that materialize kind of intrinsic value in them of human. However, the characters had to be established, was spread out, and built consciously and purposefully through the educational process.

As with the other areas, there are different ways to achieve a set of educational objectives. For values education, methods, programs, and curriculum has been developed to help the younger generation in order to achieve a life more personally satisfying and socially more constructive. Judging from its substance, there are four approaches were considered as the main movement in the field of constructive values education, namely: (1) the realization of value, (2) character education, (3) civic education, and (4) moral education (Zuchdi, 2009). As described in an earlier description that in a papaseng contained a big idea, a noble mind, precious soul, and a sublime considerations on the nature of the good and bad. Great value in a pappaseng packaged in a concept with an abstract meaning so as to understand the meaning that requires specific approaches, because it does not cover the possibility that pappaseng the meaning behind it is circumstantial.

Pappaseng can be said to be synonymous with meaningful advice pangaja, but pappaseng is not quite the same with the word pangaja meant ' advice'. Pappaseng more emphasis on moral teachings should be kept, while the pangaja emphasis on an action that needs to be done or avoided (Mone, 2010).

As a form of expression of the mind, pappaseng are often presented in the various events, meetings, wedding, and speeches and so on. In public speaking, speakers usually deliver the pappaseng to turn the atmosphere. Usually the delivery of a speech combined with pappaseng will not be boring and more interesting for the listener. Listeners will usually be more serious because pappaseng delivered it contained moral messages which felt very helpful in living a life. Nevertheless, it is expected that pappaseng not only limited to be heard, but the most important is how pappaseng it is practiced and implemented in various aspects of life.

In relation to the value of the education efforts as one of alternative values education and character, some writers have previously been presented with a variety of approaches, methods and strategy. The author suggests some opinions as follows:

a. Wening (2013) suggested several strategies in character education, namely: (1) learning in schools should integrate the values of life through the subject matter conveyed by teachers, (2) teachers need to know and apply the value of learning strategies in accordance with the meaning of the word value, namely a) value identification, b) activity, c) learning aids, d) unit of interaction, and e) evaluation segment.

b. Aswandi (2010) suggests that building a nation through character education can be done through three important things, namely: (1) conditioning, (2) minimal model for example; and (3) integrated education.

c. Harianti (2013) explained that the application of character education requires the cooperation of many parties and also require examples of educational personnel, educators, and parents.

d. Husaini (2013) emphasizes that character education developed in Indonesia, particularly for Muslims, to be Unity of god as based character education.

e. Samsuri (2011) suggests that the ideal character education should include aspects of the formation of the personality that contains the dimensions of the virtues of universal values and cultural awareness in which norms of life 
to grow and thrive. In summary, character education transcendental consciousness is able to make individuals capable of constructive behavior in be applied based on the context of a life where he is: has the global consciousness, but is able to act according to local context.

Based on the opinion of some, it can be summarized that shared the values education and character can be done with a few strategies that are considered effective, among others: (1) should be integrated in a variety of learning activities, both formal and informal, (2) values education and character need exemplary, not only theory, (3) in its implementation needs conditioning, (4) should reflect back and based on the virtues of universal values that have been embedded in the cultural life of the past with norms of life that are arranged in the form of culture without neglecting the awareness global.

\section{CONCLUSION}

The main values that are contained in the pappaseng include: the value of alempureng (Honesty), réso (hard work), assitulung-tulungeng, assiwolompolongeng (mutual cooperation), agettengeng(Firmness), awaraningeng (Courage), Sipakatau (humanizing respect). A fundamental human value which is the philosophy of the society since Bugis ancient can be a sturdy grounding in Bugis society character formation in particular and the nation in general character.

The concerns of the various parties about the character education is currently showing the condition of education that is truly serious, and should be addressed seriously, and one of the best alternative is to "restore the society to Culture" in the sense that includes ways of thinking, viewpoints and beliefs that can form a value that becomes the cornerstone of the formation of attitudes, behaviors, and actions of the community. Without concern for local wisdom values and let the panngadereng system ' culture, ' ravaged by a current swept the modernization of global lifestyle with a very strong character, this nation will be crushed to pieces, morality becomes something that is not important anymore, hollering at each other, acts of violence, and destroy each other no matter again, violations of the law occurred everywhere no matter, all become the phenomenon of life in the era of modernization and globalization.

Values education and character can be done with some effective strategies, among other things: (1) be integrated in a variety of learning activities, both formal and informal, (2) performed by giving the example, not only theory, (3) performed with conditioning, (4) should reflect back and based on the virtues of universal values that have been embedded in the cultural life of the past with norms of life that are arranged in the form of culture without neglecting global awareness.

\section{REFERENCES}

[1] Enre, Ambo., Fachruddin., et al. (1985). Pappasenna to Maccaé ri Luwuq sibawa Kajao Laliddong ri Boné. Ujung Pandang: Depdikbud, Proyek Penelitian dan Pengkajian Kebudayaan Sulawesi Selatan La Galigo.

[2] Amir., Rasdiana, Andi.,et al. (1982). Bugis-Makassar in map Islamization. Ujung Pandang: IAIN Alauddin.

[3] Putra, Ani. \& Bagus, Ghazali. (2010). Build the Civilization of a Nation with the Moral Character Education. [Online]. http://pks.psikologi.unair.ac.id/coretan-kami/membangun-peradaban-bangsa-dengan-pendidikan-berkarakter-moral/, (Accessed on 10th January 2013).

[4] Aswandi. (2010). Building a nation through educational character. [Online]. http://inspirasitabloid.wordpress.com/2010/08/10/membangun-bangsa-melalui-pendidikan-karakter/) Access on 11th January 2013).

[5] Depdiknas. (2007). Indonesian Language Dictionary. Jakarta: Balai Pustaka,

[6] Depdiknas. (2000). The value of Educational Pappaseng in Bugis Literature. Bunga Rampai Hasil Penelitian Bahasa dan Satra I. Makassar: Depdiknas, Pusat Pembinaan dan Pengembangan Bahasa.

[7] Depdiknas. (2010). The value of culture in Pappaseng Tomatoa: Ancestry Advice Bunga Rampai Hasil Penelitian: Bahasa dan Sastra. Ujung Pandang: Balai Bahasa,.

[8] Haddade, Muh.Naim. (1986). The phrase, Proverb, and Bugis Paseng: literature. Jakarta: Depdikbud, Proyek Penerbitan Buku Sastra Indonesia dan Daerah.

[9] Hakim, Zainuddin. (1990). Messages and Paruntukkana in classical literature Makassar. Jakarta: Pusat Pembinaan dan Pengembangan Bahasa

[10] Harianti, Diah. (2013). The effectiveness of character education need the cooperation of teachers and parents. Kompas Wednesday 16th October 2013. [Online]: http://edukasi.Kompas.com/read/2013/10/16/1358103/Efektivitas. Pendidikan.KarakterButuh.Kerja.Sama.Guru.dan Orang.Tuasaripediawordpress.com/tag/pendidikan-karakter/. Acces on 17th January 2014.

[11] Husaini, Ardian. (2013). Educational Character. [Online]. http:// saripediawordpress. com/tag/pendidikan-karakter/. Access on $11 / 1 / 2013$.

[12] Koesoema A, Doni. (2010). Character education, strategies to educate in a Global Era. Jakarta: PT Gramedia Widiasarana.

[13] Mattalitti, M. Arif, et al. (1986) Pappaseng To Riolotak. Ujung Pandang: Balai Penelitian Bahasa

[14] Matthes, B.F. (1872). Boegineesche Chrestomathie. III. Gedrukt Te Amstterdam BU. Amsterdam: C. A. Spin \& Zoon Het Nederlandsch Gouvernement.

[15] Matthes, B.F. (1937). Boegineesche Chrestomathie. BIJ Belmagazijn. Amsterdam: Batavia Uitgegeven Voor Rekening-van Het Nederlandsch-BIJ Belgendotschap Amsterdam.

[16] Mattulada. (1995). Latoa: A Painting of Analytical Political Anthropology of Bugis. Ujung Pandang: Hasanuddin University Press.

[17] Punagi, Andi Abu Bakar. (1989). Pappaseng (People testament of the past). Ujung Pandang: Yayasan Kebudayaan Sulsel. 
[18] Rahman, Bujang. (2013). Reconstruction of the paradigm of Education to strengthen the Character of the nation through the implementation of the curriculum. [Online]: http://fkip.unila.ac.id/wp-content/uploads/2013/09/Orasi-Ilmiah.pdf. Access on 9/1/2013.

[19] Rosmawati. (2003). Pappaseng as a philosophy of Leadership within the community of Bugis. Suatu Tinjauan Semantik. Dissertation, State University of Makassar.

[20] Said DM, M. Ide. (1977). Dictionary of Bugis-Indonesia. Jakarta: Pusat Pembinaan dan Pengembangan Bahasa.

[21] Said, D.M. (1997). The concept of work ethic according to language, literature, and culture of the Bugis. Makassar: Ujung Pandang IKIP.

[22] Samsuri. (2011). Why Character Education is Necessary? [Online]. http://eprints.uny.ac.id/ 2659/1/Mengapa_(Perlu)_Pendidikan_Karakter-_Pengalaman_FISE_UNY_Power_Point_14_Januari_2011.pdf

[23] Sariyan, Awang. (2013). Overview of national language in Malaysia. Makalah Kongres Bahasa Indonesia X di Hotel Grand Sahid Jaya Jakarta. On 28-31 oktober 2013.

[24] Sikki, et al. (1998). The value and benefits of Bugis literature Pappaseng. Jakarta: Depdikbud, Pusat Pembinaan dan Pengembangan Bahasa

[25] Soedarsono, H. Soemarno. (2008). Rebuild the nation identity: the important role of the character and the desire for change. Jakarta: PT. Elex Media Komputindo-Kompas Gramedia.

[26] Sumadi, Tjipto. (2013). Bahasa Indonesia dalam Kurikulum 2013.” Congressional papers Indonesian Language X in Hotel Grand Sahid Jaya", Jakarta, 28-31 October 2013.

[27] Sutaryo. (2012). National character education Seminar. [Online]: (http://berkarya.um.id/tag/pendidikan-karakter/). Access on $12 / 1 / 2014$.

[28] Wening,Sri. Learning Strategy Approach To Value The Life Of A Consumer-Based Character Education" [Online]: (http://staff.uny.ac.id/sites/default/files/penelitian/Sri\%20Wening,\%20Dra\%20M.Pd./PENDEKATAN\%20STRATEGI\%20

PEMBELAJARAN\%20NILAI\%20KEHIDUPAN\%20KONSUMEN\%20

BERBASIS\%20PENDIDIKAN\%20KARAKTER.pdf). Access on 15/1/ 2014.

[29] Zubair. (1995). Ethics Lecture. Jakarta: PT Raja Grafindo Persada.

[30] Zuchdi, Darmiyati. (2009). Humanization of Education. Jakarta: PT Bumi Aksara.

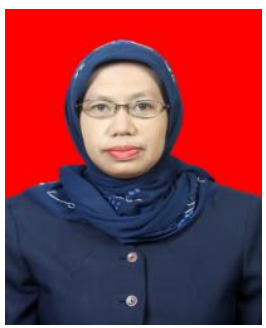

Syamsudduha was born in Garessi, Pinrang Regency, South Sulawesi province, Indonesia on May 18, 1965. She completed her primary school education (1977) in her birthplace, the first secondary school in Pinrang Regency Suppa (1981), and completed high school in Parepare Municipality. She is a graduate of the Faculty of language and literature of IKIP Ujung Pandang (1989) in Bachelor (S1), and graduate school of Hasanuddin University (1999) on the linguistic Course.

Since 1990 till now, she is still as a lecturer at the Faculty of language and literature at the State University of Makassar. Now, she gives lectures, coaching the Buginese Language Morphology and development of Plurals, and the analysis of the discourse on language and literature, Faculty of education, State Uni versity of Makassar. Some of her writings were published in book form as well as through the journal, namely; the planning of learning the language and literature of Indonesia-based theory and its application, KTSP (2009) published by the Publisher of the State University of Makassar, Vocabulary three languages: Indonesia-Makassar-Bugis, (2013), published by UD Independently Publisher, Morphological Constructions of Bugis Language (A Detail Observation of Compound Words), Journal of Civilization, Volume III Number 14, hal. 43-56, ISSN 1675-8420(2009), Contextual learning field of study Indonesian Language in junior high Country City of Makassar, Endeavour, Scientific research and Development Journal by Aktua, special editions of Pancasila's birthday June 1, 2011 116-121, ISSN 1364-8535.

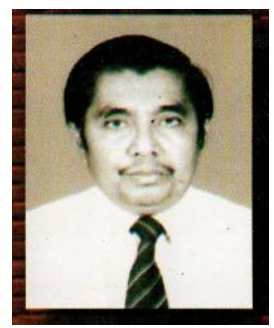

Kamaruddin, was born in Bulukumba on 15 August 1937, completed education Bachelor's degree (1960) and Bachelor (1964) in FKIP Manado. He got Master of Arts (M.A.) in Michigan State University (1979) and He got Doctorate degree in the field of Linguistics at Hasanuddin University (1992).

He became a lecturer since 1960 until now. He is an Indonesian Language Teacher Instructor Department of P and K (1975-1976), Director of Research Development of a Coordinated Educational Intervention System for Improving the Quality of Life of the Rural Poor through Self-Reliance (Delsilife) Seameo-Innotech Cooperation. He is also the linguistic community member Indonesia (Masyarakat Linguistik Indonesi/MLI) and the set Builder Indonesian Language (Himpunan Pembina Bahasa Indonesia/HPBI). He actively attended literary seminars and conferences both national and international.

He compiled several books, namely: being bilingual and dual language Education (1989), Principal of Psycholinguistics (1992), applied psycholinguistics: introduction to psychology of learning and teaching languages (1972),

He delivered a Scientific Oration Entitled Basic Education Empowerment through Education dual language Approach (1999).

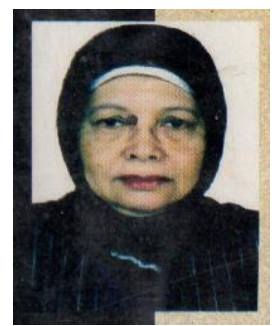

Hawang Hanafi, was born on December 24, 1941 in Siwa Wajo Regency. She completed his Bachelor's degree (B.A.) from the University of Pajajaran, Bandung (1963), Complete Scholars at FKSS IKIP Bandung (1965). She completed his Master of Science degree in the field of Linguistic studies of Hasanuddin University (1988), doctoral Program in Linguistics Studies Subprograms Hasanuddin University Makassar (1992).

In 1966, she was appointed permanent lecturer in FKSS IKIP Ujung Pandang, Indonesia majoring in English language and literature. The inaugural great teacher was in October 1998. 
She had served as Associate Dean of the field of financial administration, Assistant Dean of Academics at FBS IKIP Ujung Pandang, Chairman of the Community Service Agencies (LPM). A series of seminars, workshops, activities and training have been attended, either as participants, main responders or presenter, both in domestic and in foreign countries, such as Brunei Darussalam, Malaysia, Singapore, and Tunisia (North Africa).

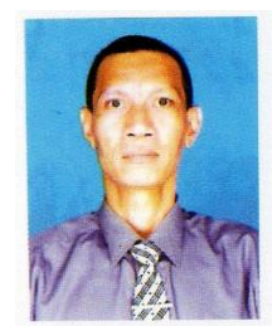

Muhammad Rapi Tang was born on December 30, 1960 in Enrekeng, Soppeng Regency, South Sulawesi, Indonesia. He obtained Bachelor's degree Education of language and literature of Indonesia (1986), a Master of Science degree in the field of study of science literature (1992). He is a lecturer at the Polytechnic University of Agriculture of hasanuddin University 1987-1989, Guest Lecturer on relating the "AmericanEnglish Exchange Foundation (Aminef) at the University of Wisconsin United States June-August 1994, doctoral/in the field of literary studies since (2001).

His functional titles are great teachers in the fields of literature, during his duties, was chief of the laboratory of language and literature of Indonesia and the region, the Faculty of Arts, languages and Makassar State University (1993-1995), Chairman of the Indonesia Literary Studies Program, Department of language and literature of Indonesia and the region, the Faculty of Arts, languages and Makassar State University (2003-2006), Chairman of the Department of language and literature of Indonesia and the region, the Faculty of language and art The Makassar State Uni versity, 2006-2010.

Various scientific activities have been followed: symposia, training who once followed, either as participants or as a presenter, such as: Southeast Asian Nations Literature Conference 2002. He also follows the "Training of Trainers" of human rights (human rights), Cooperation Human Rights Protection - Director-General of the national police - Unhcr (the United Nations). 